\title{
Molybdate Reduction to Molybdenum Blue by an Antarctic Bacterium
}

\author{
S. A. Ahmad, ${ }^{1}$ M. Y. Shukor, ${ }^{1}$ N. A. Shamaan, ${ }^{2}$ W. P. Mac Cormack, ${ }^{3}$ and M. A. Syed ${ }^{1}$ \\ ${ }^{1}$ Department of Biochemistry, Faculty of Biotechnology and Biomolecular Sciences, Universiti Putra Malaysia, \\ 43400 Serdang, Selangor, Malaysia \\ ${ }^{2}$ Faculty of Medicine and Health Sciences, Universiti Sains Islam Malaysia, 13th Floor, Menara B, Persiaran MPAJ, \\ Jalan Pandan Utama, Pandan Indah, 55100 Kuala Lumpur, Malaysia \\ ${ }^{3}$ Instituto Antartico Argentino, Cerrito 1248 (1010), Buenos Aires, Argentina \\ Correspondence should be addressed to M. Y. Shukor; mohdyunus@upm.edu.my
}

Received 24 July 2013; Revised 22 October 2013; Accepted 9 November 2013

Academic Editor: Marcelo A. Soares

Copyright (C) 2013 S. A. Ahmad et al. This is an open access article distributed under the Creative Commons Attribution License, which permits unrestricted use, distribution, and reproduction in any medium, provided the original work is properly cited.

A molybdenum-reducing bacterium from Antarctica has been isolated. The bacterium converts sodium molybdate or Mo ${ }^{6+}$ to molybdenum blue (Mo-blue). Electron donors such as glucose, sucrose, fructose, and lactose supported molybdate reduction. Ammonium sulphate was the best nitrogen source for molybdate reduction. Optimal conditions for molybdate reduction were between 30 and $50 \mathrm{mM}$ molybdate, between 15 and $20^{\circ} \mathrm{C}$, and initial $\mathrm{pH}$ between 6.5 and 7.5. The Mo-blue produced had a unique absorption spectrum with a peak maximum at $865 \mathrm{~nm}$ and a shoulder at $710 \mathrm{~nm}$. Respiratory inhibitors such as antimycin A, sodium azide, potassium cyanide, and rotenone failed to inhibit the reducing activity. The Mo-reducing enzyme was partially purified using ion exchange and gel filtration chromatography. The partially purified enzyme showed optimal $\mathrm{pH}$ and temperature for activity at 6.0 and $20^{\circ} \mathrm{C}$, respectively. Metal ions such as cadmium, chromium, copper, silver, lead, and mercury caused more than $95 \%$ inhibition of the molybdenum-reducing activity at $0.1 \mathrm{mM}$. The isolate was tentatively identified as Pseudomonas sp. strain DRY1 based on partial 16s rDNA molecular phylogenetic assessment and the Biolog microbial identification system. The characteristics of this strain would make it very useful in bioremediation works in the polar and temperate countries.

\section{Introduction}

Heavy metals pollution is a global problem. Remediation of heavy metals contaminated sites by bacteria is becoming more and more important. Microbes have the amazing ability to resist the toxicity of heavy metals and this property is useful for bioremediation purposes [1-4]. It is very toxic to ruminants and its bioremediation has been reported [5]. Traces of heavy metals due to anthropogenic sources have been found in soils in Antarctic and toxicity effects on fish in the surrounding area have been reported to occur [6-8]. Few studies have been carried out to study the possibility of microbes for the remediation of heavy metals in cold regions. Low temperature microbial reduction of chromium [9] and mercury [10] has been reported.

Molybdenum is a ubiquitous metal and often pollution of this metal comes from mining operations and anthropogenic sources [11]. Molybdenum is fast becoming a global pollutant. Its pollution ranging from several hundreds to thousands of part per million has been documented in water and soils all around the world $[11,12]$. It is not toxic to human but deadly to ruminants at several parts per million [13]. Molybdenum deposits have been identified in Antarctica [14] and although these deposits have been banned from mining by the Madrid protocol, the ban is up for review in 2041 [15]. Even without the presence of mining activities, molybdenum has been found as a pollutant in Antarctica due to anthropogenic sources [8]. There is very limited study on the effects of heavy metals to terrestrial Antarctic organisms and precautionary steps in removing heavy metals pollution should be taken.

Bioremediation using microbes may be the only cheap and workable technology to remediate metal contaminants in Antarctica and other cold regions. Thus it is vital that coldtolerant molybdenum-reducing microbes are isolated from 
polar regions as a preparative step for future bioremediation works. It is also anticipated that other cold region areas would benefit from this research. In this work we report on the isolation and characterization of a psychrotolerant bacterium with the ability to transform molybdenum to the insoluble molybdenum blue. This is the first molybdenum-reducing bacterium isolated from cold region. This bacterium could be used in future remediation works of molybdenum in Antarctica and cold climate regions.

\section{Experimental}

2.1. Isolation of Molybdenum-Reducing Bacterium. Samples were collected from jubany Station, an Argentinean Base on King George Island, South Shetlands Islands, Antarctica $\left(61.5^{\circ} \mathrm{S} 54.55^{\circ} \mathrm{W}\right)$ in the austral summer 2002-2003 expedition. Soils were collected $15-20$ centimetres $(\mathrm{cm})$ beneath the surface and were placed in sterile screw-capped vials. The samples were immediately placed in a freezer and stored at $-20^{\circ} \mathrm{C}$ until returned to the laboratory for further examination. About five grams of soil sample that was well-mixed were suspended in $45 \mathrm{~mL}$ of $0.9 \%$ saline solution. A suitable serial dilution of soil suspension was then spread plated onto an agar of low phosphate medium (LPM) $(2.8 \mathrm{mM}$ phosphate) $(\mathrm{pH} \mathrm{7.0)}$. The medium (w/v) consisted of glucose (1\%), $\mathrm{MgSO}_{4} \cdot 7 \mathrm{H}_{2} \mathrm{O}(0.05 \%),\left(\mathrm{NH}_{4}\right)_{2} \mathrm{SO}_{4}(0.3 \%), \mathrm{NaCl}$ $(0.5 \%), \mathrm{Na}_{2} \mathrm{MoO}_{4} \cdot 2 \mathrm{H}_{2} \mathrm{O}(0.242 \%)$, yeast extract $(0.05 \%)$, and $\mathrm{Na}_{2} \mathrm{HPO}_{4} \cdot 2 \mathrm{H}_{2} \mathrm{O}(0.05 \%)$ to isolate molybdenum-reducing bacteria [16]. After 72 hours of incubation at $10^{\circ} \mathrm{C}$ several white and blue colonies appeared. The colony exhibiting the strongest blue intensity was then inoculated into $50 \mathrm{~mL}$ of low phosphate medium and incubated at $10^{\circ} \mathrm{C}$ for 72 hours statically. Incubation under aerobic conditions gave lower amount of Mo-blue compared to static incubation. It was observed that during cellular reduction of molybdate, cells precipitated together with the molybdenum blue product preventing cellular growth. A portion of the growth medium containing Mo-blue was centrifuged at $10,000 \times \mathrm{g}$ for $10 \mathrm{~min}$ and the supernatant was scanned from 400 to $980 \mathrm{~nm}$ using a Cintra 5 spectrophotometer. A freshly prepared low phosphate medium was used for baseline correction. This bacterium was kept in the Bioremediation and Bioassay Laboratory (Lab 204). The production of molybdenum blue in the culture supernatant was monitored at $865 \mathrm{~nm}$. Identification of the bacterium was performed by using molecular phylogenetics studies and Biolog GN MicroPlate (Biolog, Hayward, CA, USA) according to the manufacturer's instructions.

2.2. Optimization of Molybdenum Reduction. Optimization of several parameters that support molybdenum reduction to molybdenum blue such as temperature, $\mathrm{pH}$, the effect of carbon sources as electron donors, the effect of nitrogen sources, sodium molybdate, and phosphate concentrations were studied using the LPM in Section 2.1 as the basal medium for 48 hours statically.

2.3. 16s rDNA Gene Sequencing and Phylogenetic Analysis. Extraction of genomic DNA was performed using the alkaline lysis method [17]. PCR amplification was carried out on a Biometra T Gradient PCR (Montreal Biotech Inc., Kirkland, QC, Canada). The PCR mixture consisted of 0.5 pM of each primer, $1 x$ reaction buffer, $2.5 \mathrm{U}$ of Taq DNA polymerase (Promega), and $200 \mu \mathrm{M}$ of each deoxynucleotide triphosphate, at the final volume of $50 \mu \mathrm{L}$. Amplification of the 16s rDNA gene was carried out using the following primers; $5^{\prime}$-AGAGTTTGATCCTGGCTCAG-3 ${ }^{\prime}$ and $5^{\prime}$ AAGGAGGTGATCCAGCCGCA- $3^{\prime}$ corresponding to the forward and reverse primers of $16 \mathrm{~s}$ rDNA, respectively [18]. PCR was carried out under the following conditions: initial denaturation at $94^{\circ} \mathrm{C}$ for $3 \mathrm{~min} ; 25$ cycles of $94^{\circ} \mathrm{C}$ for $1 \mathrm{~min}, 50^{\circ} \mathrm{C}$ for $1 \mathrm{~min}$, and $72^{\circ} \mathrm{C}$ for $2 \mathrm{~min}$; a final extension at $72^{\circ} \mathrm{C}$ for $10 \mathrm{~min}$. Cycle sequencing was subsequently performed with the Big Dye terminator kit (Perkin-Elmer Applied Biosystems) as recommended by the manufacturer. Sequence data were initially recorded and edited using CHROMAS version 1.45. The resultant 1452 bases were compared with the GenBank database using the Blast server at NCBI (http://www.ncbi.nlm.nih.gov/BLAST/). Analysis showed that this sequence to be closely related to $\operatorname{rrs}$ from Gammaproteobacteria. The 16s rRNA ribosomal gene sequence for this isolate has been deposited in GenBank under the accession number DQ226202.

2.4. Phylogenetic Analysis. Twenty-three 16S rRNA gene sequences closely matched to isolate DRY1 were retrieved from GenBank and a multiple alignment of the sequences was carried out using clustal_W [19]. A phylogenetic tree was constructed by using PHYLIP, version 3.573 (J. Q. Felsenstein, PHYLIP_phylogeny inference package, version 3.573, Department of Genetics, University of Washington, Seattle, WA, USA (http://evolution .genetics.washington.edu/phylip.html)) [20], with Serratia marcescens as the outgroup in the cladogram. Evolutionary distance matrices for the neighbour-joining/UPGMA method were computed using the DNADIST algorithm program. Phylogenetic tree was inferred by using the neighbour-joining method of Saitou and Nei [21]. With each algorithm, confidence levels for individual branches within the tree were checked by repeating the PHYLIP analysis with 1000 bootstraps by the SEQBOOT program in the PHYLIP package. Majority rule (50\%) consensus trees were constructed using the Ml methods [22] and the tree was viewed using TreeView [23].

2.5. Crude Enzyme Preparation. Crude enzyme was prepared from a $2 \mathrm{~L}$ culture grown at $20^{\circ} \mathrm{C}$ for 72 hours on an orbital shaker at $150 \mathrm{rpm}$ on a modified high phosphate medium (HPM) consisting of $\mathrm{MgSO}_{4} \cdot 7 \mathrm{H}_{2} \mathrm{O}\left(0.5 \mathrm{gL}^{-1}\right)$, $\left(\mathrm{NH}_{4}\right)_{2} \mathrm{SO}_{4}\left(3 \mathrm{gL}^{-1}\right)$, yeast extract $\left(1 \mathrm{gL}^{-1}\right), \mathrm{NaCl}\left(5 \mathrm{gL}^{-1}\right)$, $\left.\mathrm{NaMoO}_{4} \cdot 2 \mathrm{H}_{2} \mathrm{O}\right)\left(12.1 \mathrm{gL}^{-1}\right.$ or $\left.50 \mathrm{mM}\right)$, glucose $\left(10 \mathrm{gL}^{-1}\right)$ as the source of electron donor, and $\mathrm{Na}_{2} \mathrm{HPO}_{4} \cdot 2 \mathrm{H}_{2} \mathrm{O}(100 \mathrm{mM})$ at $\mathrm{pH}$ 7.3. Growth at high phosphate under aerobic conditions prevents Mo-blue production but cells contained high enzyme activity. Experiments were carried out at $4^{\circ} \mathrm{C}$ unless stated otherwise. Bacterial cells were first harvested at $10000 \times \mathrm{g}$ for $20 \mathrm{~min}$ at $4^{\circ} \mathrm{C}$. The pellet was then reconstituted in $15 \mathrm{~mL}$ of $50 \mathrm{mM}$ Tris. $\mathrm{Cl}$ buffer ( $\mathrm{pH} \mathrm{7.0)}$ containing 
$1 \mathrm{mM}$ phenylmethanesulphonylfluoride (PMSF) as a protease inhibitor and $2 \mathrm{mM}$ of DTT. The cells were then sonicated on a Biosonik 111 sonicator on an ice bath and then ultracentrifuged at $105000 \times \mathrm{g}$ for $90 \mathrm{~min}$ at $4^{\circ} \mathrm{C}$. The supernatant containing the crude enzyme was collected. The enzyme had an optimum temperature at $20^{\circ} \mathrm{C}$ (data not shown).

2.6. Enzyme Assay. Enzyme was assayed at $20^{\circ} \mathrm{C}$ according to the method of Shukor et al. [24]. The reaction mixture $(1 \mathrm{~mL})$ contained $3 \mathrm{mM}$ of 12-molybdophosphate (electron acceptor substrate) in $50 \mathrm{mM}$ citrate phosphate buffer $\mathrm{pH} 5.0$ at room temperature and $100 \mu \mathrm{L}$ of $\mathrm{NADH}$ at the final concentration of $3 \mathrm{mM}$. Fifty microlitres of enzyme fraction containing about $1 \mathrm{mg}$ protein were added to start the reaction. The absorbance increase in one minute was read at $865 \mathrm{~nm}$. One unit of Mo-reducing activity is defined as the amount of enzyme that produces 1 nmole Mo-blue per minute at $20^{\circ} \mathrm{C}$. The specific extinction coefficient for the product; Mo-blue at $865 \mathrm{~nm}$ is $16.7 \mathrm{mM}^{-1} \cdot \mathrm{cm}^{-1}$ [25].

2.7. Ion Exchange and Gel Filtration Chromatography. Ammonium sulphate fractionation was omitted as it gave very low enzyme yield. The experiment was carried out at $4^{\circ} \mathrm{C}$ unless stated otherwise. Crude fraction (cytoplasmic fraction after ultracentrifuge) was directly applied to the strong anion exchange matrix Mono-Q (Amersham Pharmacia). The column was first equilibrated with $50 \mathrm{~mL}$ of $50 \mathrm{mM}$ Tris. $\mathrm{Cl} \mathrm{pH} 7.5$ (buffer A) containing 0.1 mM DTT. About 40 milligrams of the crude enzyme in $2 \mathrm{~mL}$ of volume was injected into the Mono-Q column at a flow rate of $1 \mathrm{~mL}$ per minute and then washed with $20 \mathrm{~mL}$ of the same buffer. Enzyme was eluted from the column with a linear gradient of $0-0.5 \mathrm{M} \mathrm{NaCl}$ in buffer $\mathrm{A}$ at a flow rate of $1 \mathrm{~mL} \mathrm{~min}^{-1}$. The protein elution profile was monitored at $280 \mathrm{~nm}$. This process was repeated several times until the entire crude fraction was loaded into the column.

The fractions with enzyme activity were pooled and dialyzed against $5 \mathrm{~L}$ of buffer A overnight. The dialyzed enzyme was then concentrated using a cellulose triacetate filter membrane with a molecular weight cut-off point of $10 \mathrm{kDa}$ in an Amicon ultrafiltration cell at $4^{\circ} \mathrm{C}$ to a final volume of $0.5 \mathrm{~mL}$. One hundred microlitres of sample containing $1.2 \mathrm{mg}$ of protein was applied to Zorbax GFC-250 column $(250 \times$ $9.4 \mathrm{~mm}$ ) and eluted using buffer A containing $0.2 \mathrm{M} \mathrm{KCL}$ at a flow rate of $0.5 \mathrm{~mL} \mathrm{~min}^{-1}$. Protein was quantified according to the method of Bradford [26] using BSA as the standard. Michaelis Menten kinetics constants were determined using GraphPad prism nonlinear regression analysis available from http://www.Graphpad.com.

2.8. The Effects of Respiratory Inhibitors and Metal Ions. Respiratory inhibitors such as antimycin A, sodium azide, potassium cyanide, and rotenone were dissolved in acetone or deionised water and were added into enzyme assay mixture to the final concentrations of $1.2,10,10$, and $0.2 \mathrm{mM}$. Metal ions such as $\mathrm{Cr}^{6+}\left(\mathrm{K}_{2} \mathrm{Cr}_{2} \mathrm{O}_{7}, \mathrm{BDH}\right), \mathrm{Fe}^{3+}$ $\left(\mathrm{FeCl}_{3} \cdot 6 \mathrm{H}_{2} \mathrm{O}, \mathrm{BDH}\right), \mathrm{Zn}^{2+}\left(\mathrm{ZnCl}_{2}, \mathrm{BDH}\right), \mathrm{Mg}^{2+}\left(\mathrm{MgCl}_{2}\right.$, $\mathrm{BDH}), \mathrm{Co}^{2+}\left(\mathrm{CoCl}_{2} \cdot 6 \mathrm{H}_{2} \mathrm{O}, \mathrm{BDH}\right), \mathrm{Ni}^{2+}\left(\mathrm{NiCl}_{2} \cdot 6 \mathrm{H}_{2} \mathrm{O}, \mathrm{BDH}\right)$,
$\mathrm{Cd}^{2+}\left(\mathrm{CdCl}_{2} \cdot \mathrm{H}_{2} \mathrm{O}\right.$, SparkChem $), \mathrm{Ag}^{+}\left(\mathrm{AgNO}_{3}, \mathrm{JT}\right.$ Baker $)$, $\mathrm{Mn}^{2+}\left(\mathrm{MnCl}_{2} \cdot 4 \mathrm{H}_{2} \mathrm{O}\right.$, JT Baker $), \mathrm{Cu}^{2+}\left(\mathrm{CuSO}_{4} \cdot 5 \mathrm{H}_{2} \mathrm{O}\right.$, JT Baker), $\mathrm{Hg}^{2+}\left(\mathrm{HgCl}_{2}\right.$, JT Baker), and $\mathrm{Pb}^{2+}\left(\mathrm{PbCl}_{2}\right.$, JT Baker) were dissolved in $20 \mathrm{mM}$ Tris. $\mathrm{Cl}$ buffer $\mathrm{pH} 7.0$ and were added into enzyme assay mixture to the final concentration of $0.1 \mathrm{mM}$. Inhibitors and metal ions were then preincubated with $100 \mu \mathrm{L}$ of enzyme in the reaction mixture at $4^{\circ} \mathrm{C}$ for 10 minutes minus NADH. The incubation mixture was then warmed to $20^{\circ} \mathrm{C}$ and $100 \mu \mathrm{L}$ of NADH at the final concentration of $3 \mathrm{mM}$ was added to start the reaction. Deionised water was added so that the total reaction mixture was $1.0 \mathrm{~mL}$. As a control, $50 \mu \mathrm{L}$ of acetone was added in the reaction mixture without inhibitors.

2.9. Dialysis Tubing Experiment. Briefly, the bacterium was grown in $250 \mathrm{~mL}$ high phosphate medium with shaking at $150 \mathrm{rpm}$ at $20^{\circ} \mathrm{C}$ for 72 hours. Cells were harvested by centrifugation at $15,000 \mathrm{~g}$ for 10 minutes. The pellet was washed several times with distilled water and then resuspended in $50 \mathrm{~mL}$ of low phosphate solution $\left(\mathrm{pH} \mathrm{7.0)}\right.$ at $20^{\circ} \mathrm{C}$ containing (w/v) $\mathrm{MgSO}_{4} \cdot 7 \mathrm{H}_{2} \mathrm{O}(0.05 \%), \mathrm{NaCl}(0.5 \%),\left(\mathrm{NH}_{4}\right)_{2} \mathrm{SO}_{4}$ $(0.3 \%)$, yeast extract $(0.05 \%)$, and $\mathrm{Na}_{2} \mathrm{HPO}_{4} \cdot 2 \mathrm{H}_{2} \mathrm{O}(0.05 \%)$ with sodium molybdate omitted. About $10 \mathrm{~mL}$ of this suspension was transferred into dialysis tubing that was previously boiled for ten minutes ( $12 \mathrm{kDa}$ molecular weight cutoff). The tube was then immersed in sterile $50 \mathrm{~mL}$ of low phosphate medium ( $\mathrm{pH} 7.0$ ) for 10 hours at $20^{\circ} \mathrm{C}$ statically as described in Section 2.1. Periodically, aliquots $(1 \mathrm{~mL})$ of the external medium were taken at the start of the experiment and after an incubation period of 10 hours and then the molybdenum blue produced was monitored at $865 \mathrm{~nm}$. At the same time, $1 \mathrm{~mL}$ was taken out from the dialysis tubing and centrifuged at $15,000 \mathrm{~g}$ for 10 minutes. The supernatant was then read at $865 \mathrm{~nm}$. Experiments were carried out in triplicate.

2.10. Statistical Analysis. Values are means \pm SE. All data were analyzed using Graphpad Prism version 3.0 and Graphpad InStat version 3.05 available at www.graphpad.com. Comparison between groups was performed using a Student's $t$-test or a one-way analysis of variance with post hoc analysis by Tukey's test. $P<0.05$ was considered statistically significant.

\section{Results}

3.1. Identification of the Isolate. A low bootstrap value $(<50 \%)$ was seen associating isolate DRY1 to several Pseudomonas species such as P. panacis, P. fulgida, P. gessardii, P. mucidolens, $P$. azotoformans, and $P$. reactants indicating that the tying up of isolated DRY1 to any Pseudomonas species cannot be done at this moment. The identifications performed by Biolog GN also gave no conclusive identification to the species level with the closest identification to several Pseudomonas species with very low probability. For now, isolate DRY1 is assigned tentatively as Pseudomonas sp. strain DRY1 (Figure 1).

3.2. The Effect of Electron Donor on Molybdate Reduction. The electron donor glucose, sucrose, fructose, and lactose supported molybdate reduction in decreasing order of efficiency 


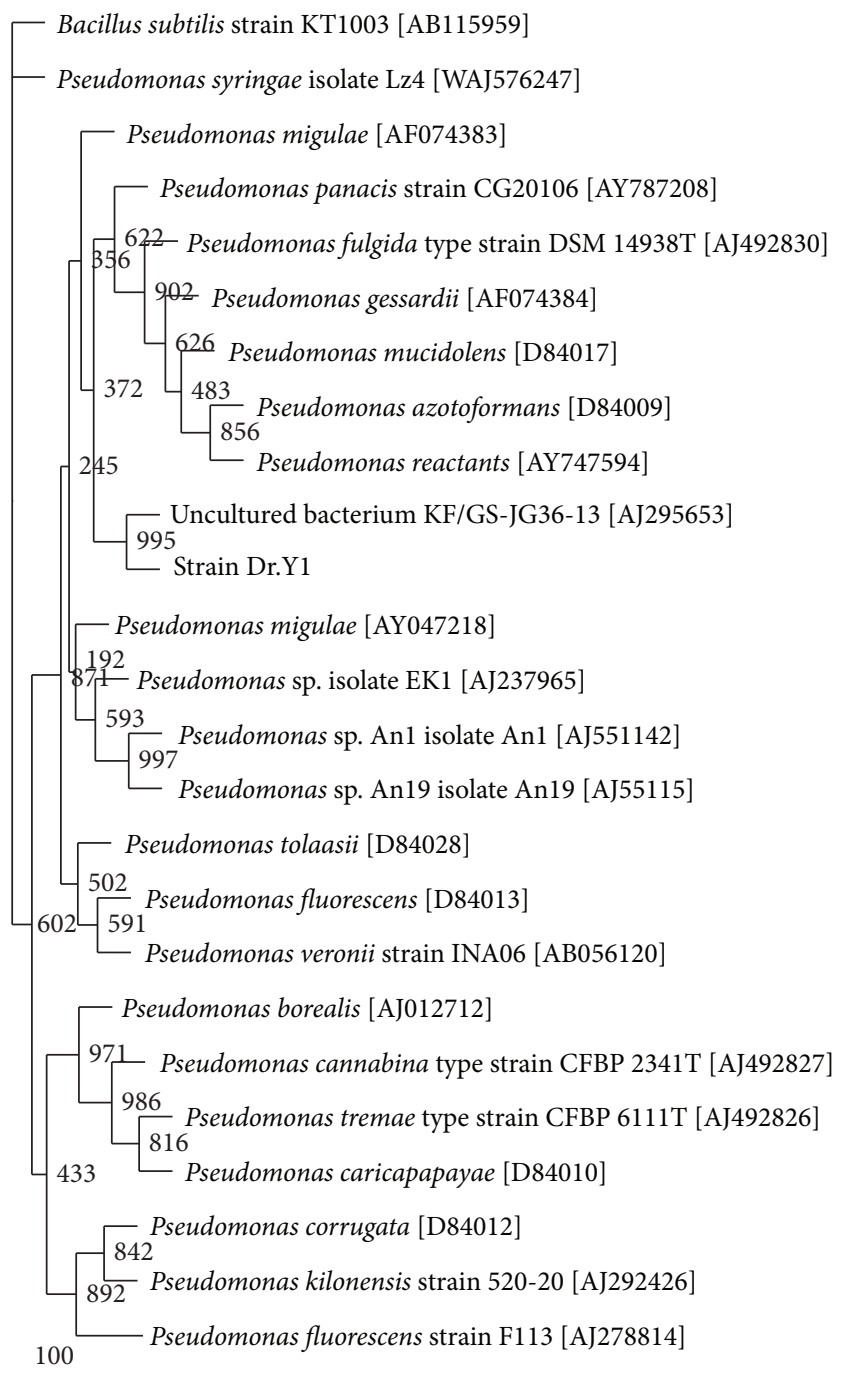

FIGURE 1: A phylogram (neighbour-joining method) showing genetic relationship between strain DRY1 and other related reference microorganisms based on the 16S rRNA gene sequence analysis. Species names are followed by the accession numbers of their $16 \mathrm{~S}$ rRNA sequences. The numbers at branching points or nodes refer to bootstrap values, based on 1000 resamplings. Scale bar represents 100 nucleotide substitutions. B. subtilis is the outgroup.

with glucose and sucrose exhibiting more than four times the amount of Mo-blue compared to lactose and fructose (Figure 2). Optimum molybdate reduction was achieved at $1 \%(\mathrm{w} / \mathrm{v})$ glucose after 72 hours (data not shown). The exploitation of the Biolog's carbon sources as electron donors for molybdate reduction was not possible since we discovered that the purplish color of the reduced formazan was too intense and masked the appearance of molybdenum blue. The Biolog system utilizes 95 carbon sources as a metabolic fingerprint for microbial identification.

3.3. The Effect of Nitrogen Sources on Molybdate Reduction. The effect of nitrogen sources on molybdate reduction

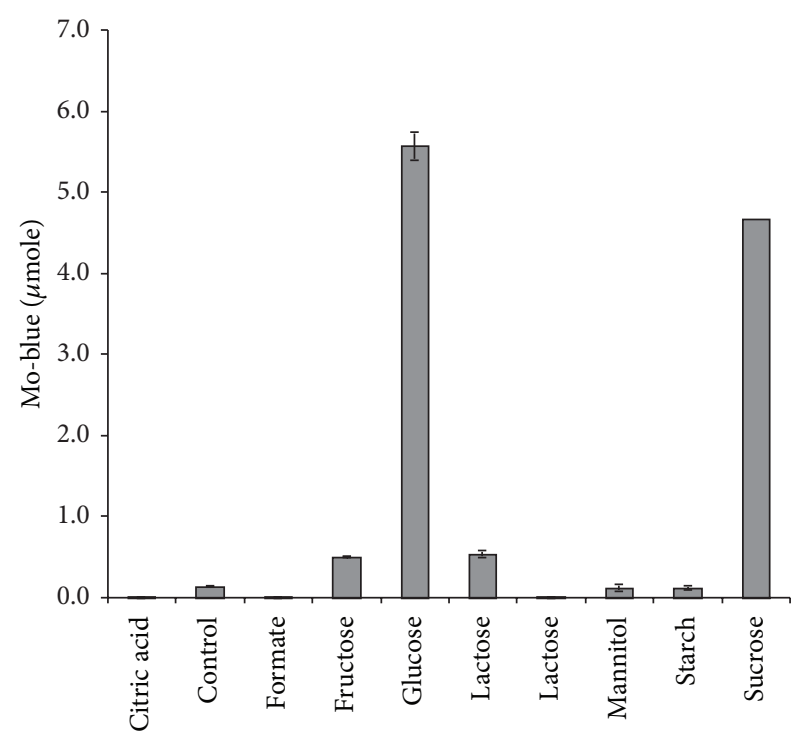

FIgURE 2: Molybdate reduction using various electron donors. Isolate DRY1 was grown at $10^{\circ} \mathrm{C}$ for 72 hours in low phosphate liquid medium ( $\mathrm{pH} 7.0$ ) containing (w/v) $\mathrm{MgSO}_{4} \cdot 7 \mathrm{H}_{2} \mathrm{O}(0.05 \%)$, $\left(\mathrm{NH}_{4}\right)_{2} \mathrm{SO}_{4}(0.3 \%), \mathrm{NaCl}(0.5 \%), \mathrm{Na}_{2} \mathrm{MoO}_{4} \cdot 2 \mathrm{H}_{2} \mathrm{O}(0.242 \%)$, yeast extract $(0.05 \%)$, and $\mathrm{Na}_{2} \mathrm{HPO}_{4} \cdot 2 \mathrm{H}_{2} \mathrm{O}(0.05 \%)$ and various electron donors at the final concentration of $0.2 \%$. Molybdate reduction is considered negligible if the absorbance at $865 \mathrm{~nm}$ is below 0.020 . Error bars represent mean \pm standard error $(n=3)$.

was studied using ammonium formate, ammonium sulphate, ammonium chloride, sodium nitrate, sodium nitrite, oxaloacetate and the amino acids alanine, asparagine, aspartic acid, valine, cysteine, glutamic acid, glycine, histidine, leucine and $\mathrm{OH}$-proline. Ammonium sulphate was found to be the most effective supplement for supporting molybdate (Figure 3). Concentrations of ammonium sulphate giving optimum molybdate reduction were between $0.2 \%$ and $0.3 \%$. Further increase in ammonium sulphate concentration shows a strong inhibitory effect on molybdate reduction (data not shown).

3.4. The Effect of Temperature and Initial pH on Molybdate Reduction. The effect of temperature on molybdate reduction was carried out at temperatures from 0 to $40^{\circ} \mathrm{C}$. The optimum temperature for molybdate reduction was in between 10 and $20^{\circ} \mathrm{C}$ (Figure 4) with ANOVA analysis showing that there was no significant difference $(P>0.05)$ in terms of molybdate production at these temperatures. The optimum initial $\mathrm{pH}$ for reduction was between $\mathrm{pH} 6.5$ and 7.5 (Figure 5) with ANOVA analysis showing that there was no significant difference $(P>0.05)$ in terms of molybdate production at these pHs.

3.5. The Effects of Molybdate and Phosphate Concentrations on Molybdate Reduction. Molybdate reduction was discovered to increase linearly as molybdate concentration was increased from 0 to $40 \mathrm{mM}$ and reached a plateau in between the concentrations of 30 and $50 \mathrm{mM}$. Concentrations higher than $50 \mathrm{mM}$ were strongly inhibitory (Figure 6). When molybdate 


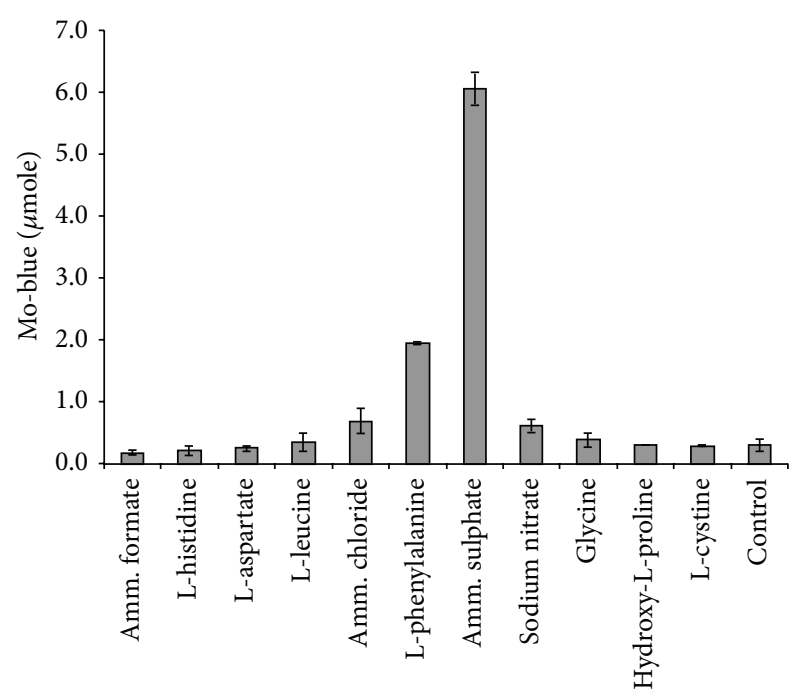

FIGURE 3: Molybdate reduction using various nitrogen sources. Isolate DRY1 was grown at $10^{\circ} \mathrm{C}$ for 72 hours in low phosphate liquid medium ( $\mathrm{pH} 7.0$ ) containing (w/v) glucose (1\%), $\mathrm{MgSO}_{4} \cdot 7 \mathrm{H}_{2} \mathrm{O}$ (0.05\%), $\mathrm{NaCl}(0.5 \%), \mathrm{Na}_{2} \mathrm{MoO}_{4} \cdot 2 \mathrm{H}_{2} \mathrm{O}(0.242 \%)$, yeast extract (0.05\%), $\mathrm{Na}_{2} \mathrm{HPO}_{4} \cdot 2 \mathrm{H}_{2} \mathrm{O}(0.05 \%)$, and various nitrogen sources at the final concentration of $0.2 \%$. Molybdate reduction is considered negligible if the absorbance at $865 \mathrm{~nm}$ is below 0.020 . Error bars represent the standard error of the mean between three determinations.

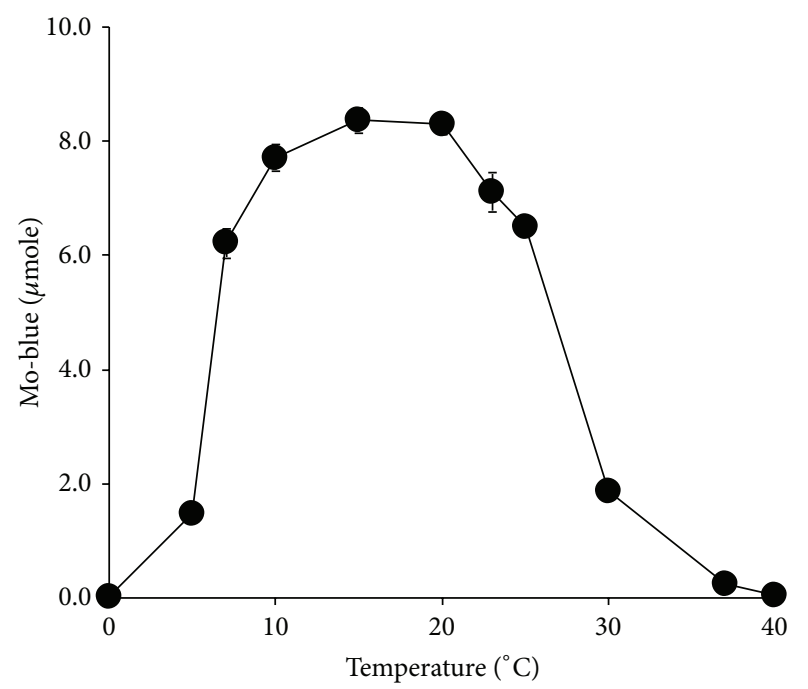

FIGURE 4: The effect of temperature on molybdate reduction by isolate DRY1. Isolate DRY1 was grown statically at various temperatures for 72 hours in $50 \mathrm{~mL}$ low phosphate liquid medium ( $\mathrm{pH} 7.0$ ) containing (w/v) glucose (1\%), $\mathrm{MgSO}_{4} \cdot 7 \mathrm{H}_{2} \mathrm{O}(0.05 \%), \mathrm{NaCl}(0.5 \%)$, $\mathrm{Na}_{2} \mathrm{MoO}_{4} \cdot 2 \mathrm{H}_{2} \mathrm{O}(0.242 \%)$, yeast extract (0.05\%), $\mathrm{Na}_{2} \mathrm{HPO}_{4} \cdot 2 \mathrm{H}_{2} \mathrm{O}$ $(0.05 \%)$, and ammonium sulphate $(0.2 \%)$. Error bars represent mean \pm standard error $(n=3)$.

concentration was fixed at $45 \mathrm{mM}$, the optimum concentration of phosphate for molybdate reduction was $5 \mathrm{mM}$. Molybdate reduction was inhibited at much higher phosphate concentrations and total inhibition occurred at $100 \mathrm{mM}$ phosphate (Figure 7).

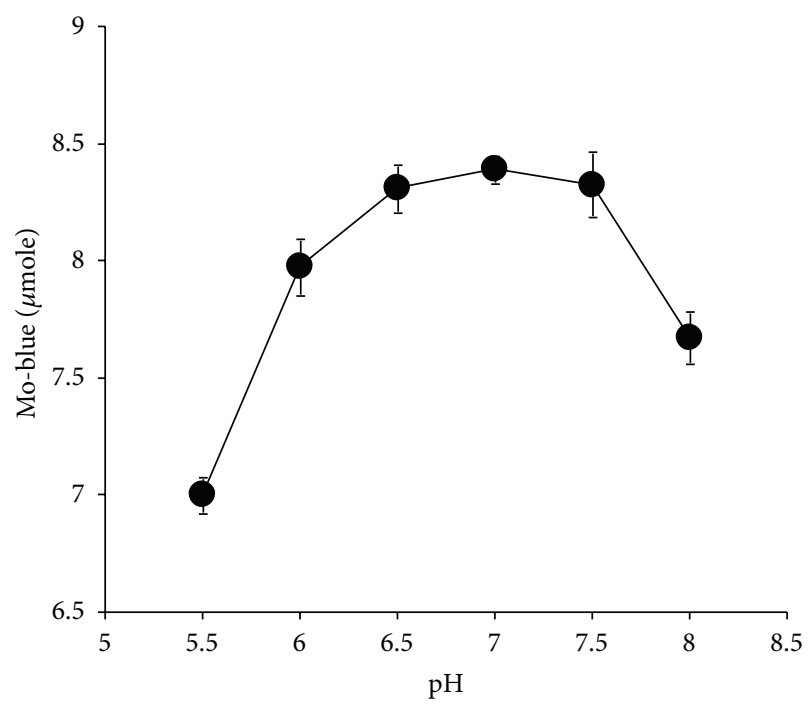

Figure 5: The effect of initial $\mathrm{pH}$ on molybdate reduction by isolate DRY1. Isolate DRY1 was grown statically at $20^{\circ} \mathrm{C}$ for 72 hours in $50 \mathrm{~mL}$ low phosphate liquid medium at various $\mathrm{pHs}$ containing (w/v) glucose (1\%), $\mathrm{MgSO}_{4} \cdot 7 \mathrm{H}_{2} \mathrm{O}(0.05 \%), \mathrm{NaCl}(0.5 \%)$, $\mathrm{Na}_{2} \mathrm{MoO}_{4} \cdot 2 \mathrm{H}_{2} \mathrm{O}(0.242 \%)$, yeast extract $(0.05 \%), \mathrm{Na}_{2} \mathrm{HPO}_{4} \cdot 2 \mathrm{H}_{2} \mathrm{O}$ $(0.05 \%)$, and ammonium sulphate (0.2\%). Error bars represent mean \pm standard error $(n=3)$.

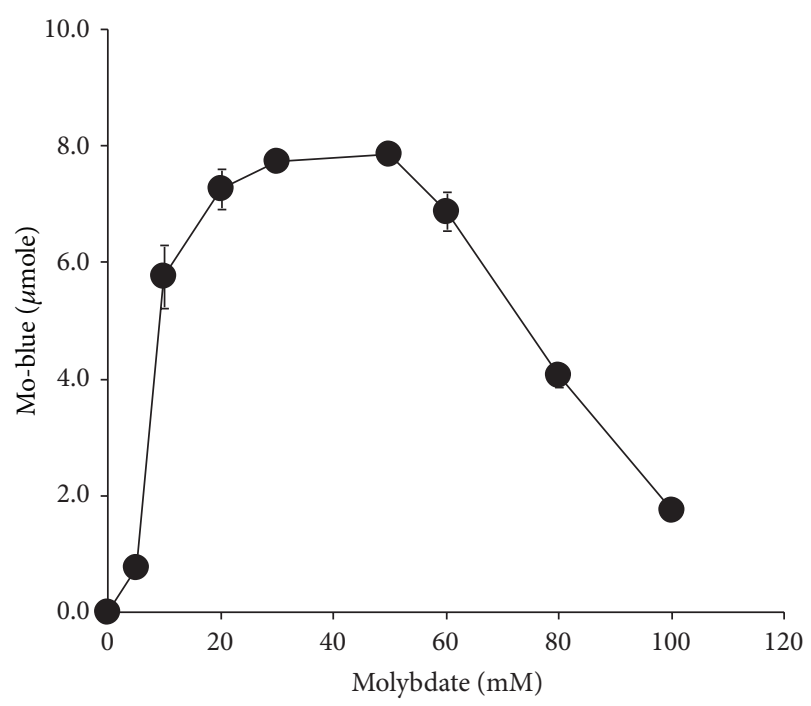

Figure 6: The effects of molybdate concentrations on molybdate reduction by isolate DRY1. Isolate DRY1 was grown at $20^{\circ} \mathrm{C}$ for 72 hours in low phosphate liquid medium $(\mathrm{pH}$ 7.0) containing $(\mathrm{w} / \mathrm{v})$ glucose $(1 \%), \mathrm{MgSO}_{4} \cdot 7 \mathrm{H}_{2} \mathrm{O}(0.05 \%), \mathrm{NaCl}(0.5 \%)$, yeast extract (0.05\%), $\mathrm{Na}_{2} \mathrm{HPO}_{4} \cdot 2 \mathrm{H}_{2} \mathrm{O}(0.05 \%)$, and ammonium sulphate $(0.2 \%)$. Error bars represent mean \pm standard error $(n=3)$.

3.6. Molybdenum Blue Absorption Spectrum. The molybdenum blue produced from this isolate showed a spectrum with an absorption profile that exhibited a maximum peak at $865 \mathrm{~nm}$ and a shoulder at $710 \mathrm{~nm}$. This unique profile increases proportionately to the blue intensity as molybdate reduction progressed (Figure 8 ). 


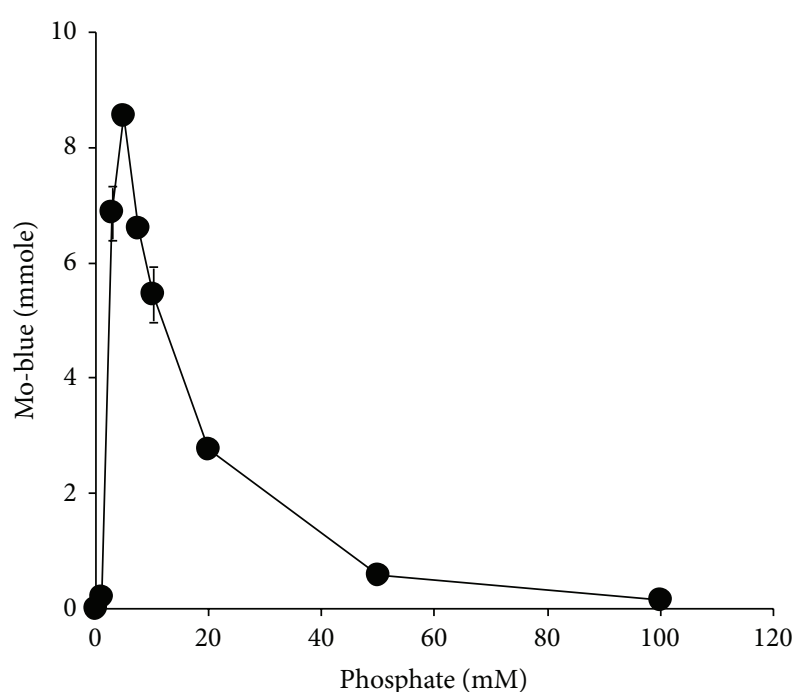

FIGURE 7: The effects of phosphate concentrations on molybdate reduction by isolate DRY1. Isolate DRY1 was grown statically at $20^{\circ} \mathrm{C}$ for 72 hours in $50 \mathrm{~mL}$ liquid medium ( $\mathrm{pH} 7.0)$ containing (w/v) glucose $(1 \%), \mathrm{MgSO}_{4} \cdot 7 \mathrm{H}_{2} \mathrm{O}(0.05 \%), \mathrm{NaCl}(0.5 \%)$, yeast extract (0.05\%), ammonium sulphate (0.2\%), $\mathrm{Na}_{2} \mathrm{MoO}_{4} \cdot 2 \mathrm{H}_{2} \mathrm{O}(1.21 \%)$, and various phosphate $\left(\mathrm{Na}_{2} \mathrm{HPO}_{4} \cdot 2 \mathrm{H}_{2} \mathrm{O}\right)$ concentrations. Error bars represent mean \pm standard error $(n=3)$.

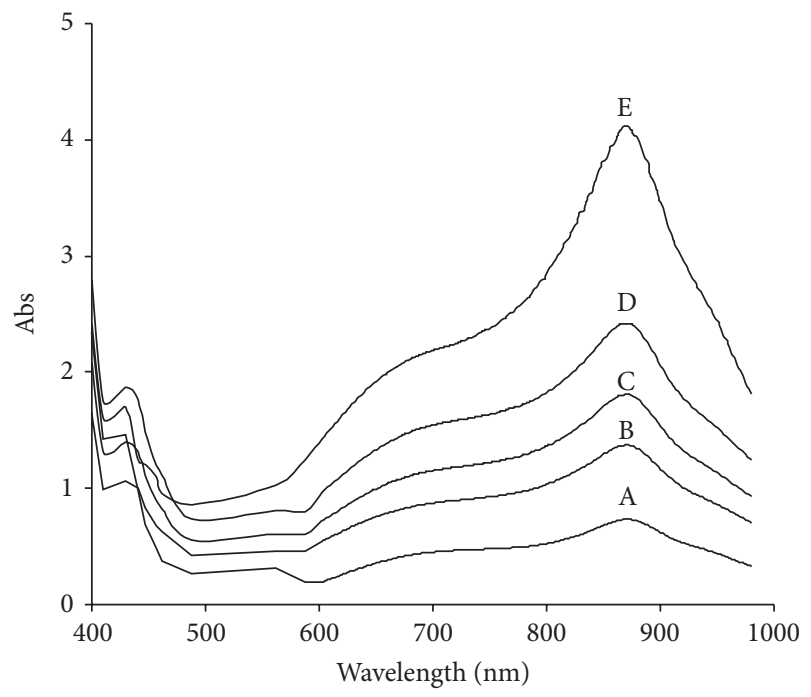

FIGURE 8: Scanning spectra of molybdenum blue after 28, 32, 36, 48, and 72 hours of static incubation at $20^{\circ} \mathrm{C}$ labeled (A), (B), (C), (D), and (E), respectively.

3.7. Characterization of the Molybdate Reduction Reaction Using the Dialysis Tubing Method. The result showed that $95 \%$ of the amount of Mo-blue formed $(13.775 \pm 0.395 \mu$ mole $)$ was found in the dialysis tube while only 5\% (1.225 \pm $0.025 \mu$ mole) was found at the outside of the tube.

3.8. Partial Purification of Mo-Reducing Activity. A five-fold purification was achieved after gel filtration but the yield was too low to incorporate another chromatographic step.
TABle 1: Partial purification scheme of Mo-reducing enzyme from Pseudomonas sp. strain DRY1.

\begin{tabular}{lccccc}
\hline Fraction & $\begin{array}{c}\text { Total } \\
\text { protein } \\
\text { (mg) }\end{array}$ & $\begin{array}{c}\text { Specific } \\
\text { activity } \\
\text { (Units/mg } \\
\text { protein) }\end{array}$ & $\begin{array}{c}\text { Total } \\
\text { activity } \\
\text { (Units) }\end{array}$ & $\begin{array}{c}\text { Yield } \\
\%\end{array}$ & $\begin{array}{c}\text { Fold } \\
\text { purification }\end{array}$ \\
\hline Crude & 400 & 3 & 1200 & 100.0 & 1.0 \\
Mono Q & 36 & 9.0 & 324 & 27 & 3.0 \\
Zorbax GFC-250 & 2.4 & 15.2 & 36.48 & 3.04 & 5.06 \\
\hline
\end{tabular}

TABLE 2: Effect of respiratory inhibitors on molybdate reduction. Data represent mean \pm standard error $(n=3)$.

\begin{tabular}{lc}
\hline Respiratory inhibitors & \% Mo-reducing enzyme activity \\
\hline Control & $100.29 \pm 10.13$ \\
Cyanide $(1.2 \mathrm{mM})$ & $102.41 \pm 8.82$ \\
Antimycin $\mathrm{A}(10 \mathrm{mM})$ & $105.71 \pm 7.35$ \\
Rotenone $(10 \mathrm{mM})$ & $91.50 \pm 5.81$ \\
Azide $(0.2 \mathrm{mM})$ & $92.60 \pm 10.73$ \\
\hline
\end{tabular}

Native-PAGE results showed that multiple bands indicating purification were not successful (data not shown). Table 1 shows that ion exchange and gel filtration chromatography removed much of the enzyme yield.

3.9. Kinetics of the Mo-Reducing Enzyme. The partially purified enzyme had an optimum $\mathrm{pH}$ for activity at 6.0 and optimum temperature for activity at $20^{\circ} \mathrm{C}$. Preliminary results show that $20 \mathrm{mM}$ phosphomolybdate (electron acceptor substrate) was saturating. A plot of initial rates against electron donor substrate concentrations at $15 \mathrm{mM}$ phosphomolybdate registered a $V_{\max }$ for NADH at $26.98 \mathrm{nmole}$ Mo blue $/ \mathrm{min} / \mathrm{mg}$ protein and an apparent $K_{m}$ of $4.68 \mathrm{mM}$. The $V_{\max }$ for $\mathrm{NADPH}$ was $29.04 \mathrm{nmole}$ Mo blue $/ \mathrm{min} / \mathrm{mg}$ protein and the apparent $K_{m}$ for NADPH was $7.39 \mathrm{mM}$.

At $25 \mathrm{mM}$ NADH (saturating NADH concentration of five times $K_{m}$ ), the apparent $V_{\max }$ and apparent $K_{m}$ values for phosphomolybdate were $23.48 \mathrm{nmole} / \mathrm{min} / \mathrm{mg}$ protein and $3.52 \mathrm{mM}$, respectively. When the electron donor substrate was NADPH, The apparent $V_{\max }$ and $K_{m}$ values for phosphomolybdate were $27.75 \mathrm{nmole} / \mathrm{min} / \mathrm{mg}$ protein and $3.8 \mathrm{mM}$, respectively.

3.10. Effect of Respiratory Inhibitors and Metal Ions on Molybdate Reduction. In this work it was discovered that none of the respiratory inhibitors tested showed any appreciable inhibition of more than $10 \%$ to the Mo-reducing activity (Table 2). Metal ions such as chromium, copper, cadmium, lead, silver, and mercury cause more than $95 \%$ inhibition of the molybdenum-reducing activity (Table 3 ). The remaining metal ions tested showed no effect on the molybdenumreducing activity. 
TABLE 3: Effect of metal ions on molybdate reduction. Data represent mean \pm standard error $(n=3)$.

\begin{tabular}{lc}
\hline Metal ions $(0.1 \mathrm{mM})$ & $\begin{array}{c}\text { Molybdenum blue produced } \\
(\mathrm{nmole} / \mathrm{min} / \mathrm{mg})\end{array}$ \\
\hline Control & $10.00 \pm 0.17$ \\
$\mathrm{Cr}^{6+}$ & $0.05 \pm 0.02$ \\
$\mathrm{Fe}^{3+}$ & $9.44 \pm 0.51$ \\
$\mathrm{Zn}^{2+}$ & $9.39 \pm 0.20$ \\
$\mathrm{Mg}^{2+}$ & $9.53 \pm 0.23$ \\
$\mathrm{Co}^{2+}$ & $9.57 \pm 0.21$ \\
$\mathrm{Ni}^{2+}$ & $9.35 \pm 0.23$ \\
$\mathrm{Cd}^{2+}$ & $0.46 \pm 0.02$ \\
$\mathrm{Ag}^{+}$ & $0.23 \pm 0.87$ \\
$\mathrm{Mn}^{2+}$ & $9.11 \pm 0.21$ \\
$\mathrm{Cu}^{2+}$ & $0.00 \pm 0.12$ \\
$\mathrm{Hg}^{2+}$ & $0.10 \pm 0.03$ \\
$\mathrm{~Pb}^{2+}$ & $0.50 \pm 0.11$ \\
\hline
\end{tabular}

\section{Discussions}

Microbial molybdate reduction to molybdenum blue is an interesting phenomenon and is important not only as a bioremediation tool but also for advancing knowledge on microbial metal reduction. According to Levine [27], molybdate-reducing property was first reported in E. coli by Capaldi and Proskauer in 1896 [28]. The first detailed study on this phenomenon was reported by Campbell et al. [29]. This is followed by Sugio et al. [30] and Ghani et al. [16]. From the year 2000 onwards, works on microbial molybdate reduction to molybdenum blue were exclusively carried out on local Malaysian isolates [24, 25, 31-40].

In this work, we report on the first isolation of a Moreducing bacterium from Antarctica and a second from the Mo-reducing bacterium from the Pseudomonas genera [40]. Further identification of the bacterium to the species level can be done by adding several more polyphasic identification methods such as 16S rRNA gene sequencing, determination of genomic DNA G+C content, DNA-DNA hybridization, and fatty acid profile [41].

Previous works have shown that easily assimilable carbon sources such as sucrose, glucose and fructose are the preferred electron donor source for molybdate reduction. In this work, glucose is the best electron donor or carbon source for supporting molybdate reduction similar to several other Mo-reducing bacteria previously reported $[16,29,37$, $39,40]$. Other Mo-reducing bacteria require sucrose $[35,36$, 38]. Ammonium sulphate as the best nitrogen source for supporting molybdate reduction in this bacterium reflects the preference of the bacterium for an easily assimilable nitrogen source and this is also shared by many of the Mo-reducing bacteria isolated so far $[16,31-40]$. Since molybdenum reduction is growth associated $[16,31-40]$, the use of glucose and ammonium sulphate as the carbon and nitrogen sources of choice, respectively, reflect a simple growth-associated process of molybdenum reduction in this bacterium. The requirement of static growth for optimal molybdate reduction may reflects a facultative anaerobic property of this bacterium. Many Pseudomonas spp. are obligate aerobes but some have been reported to be facultative anaerobes $[42,43]$.

The optimum temperature in between 10 and $20^{\circ} \mathrm{C}$ reflects a psychrotolerant property concurrent with its geographical polar origin. This strain would be very useful in bioremediation works in the polar and temperate countries. Other recently isolated molybdenum reducers exhibit higher optimal reduction in between 30 and $40^{\circ} \mathrm{C}$ [24, 25, 31-40]. Optimum $\mathrm{pH}$ that supported Mo-reduction was within the range of optimum $\mathrm{pH}$ of other Mo-reducing bacteria that varies from $\mathrm{pH} 6$ to $8[24,25,31-40]$.

Both Mo-blue, the detoxification product of molybdate, and molybdate itself are nontoxic with reported production of Mo-blue at $80 \mathrm{mM}$ molybdate in E. coli. This bacterium was able to produce comparable Mo-blue at molybdate concentrations similar to other previously isolated strains $[24,25,31-$ 40]. Furthermore it is able to reduce molybdate to Mo-blue at a high initial concentration of sodium molybdate at $100 \mathrm{mM}$. Since molybdenum pollution has been reported to reach as high as $2000 \mathrm{ppm}$ (20.8 mM molybdate) [44], tolerance and reduction at concentrations higher than $20 \mathrm{mM}$ are an advantage for a microbe. At this concentration molybdate is lethal to ruminant [45].

Phosphate is a known inhibitor towards Mo-blue production with the mechanism of inhibition involving destabilizing the phosphomolybdate intermediate involved in the reduction of molybdate $[24,25,31-40]$. In this work, the optimal concentration of phosphate supporting molybdate reduction at $5 \mathrm{mM}$ is shared by many Mo-reducing bacteria $[24,31-$ 40]. The optimum ratio of phosphate to molybdate concentrations was similar to the results obtained from Serratia sp. strain Dr.Y8 [36], Enterobacter sp. strain DrY13 [37], and S. marcescens strain Dr.Y9 [38]. This ratio is important since the formation of the proposed intermediate phosphomolybdate in molybdate reduction [31-40] is dependent on exact ratio for optimal formation $[46,47]$.

The dialysis tubing experiment showed similar result to previous works $[35,39,40]$ indicating the prominent role of enzyme(s) in molybdate reduction. The remaining molybdenum blue found in the outside of the tubing is due to a slow diffusion of the molybdenum blue as we discovered in previous works.

Amongst the metal ions, molybdenum is unique in its formation of large heteropoly structure in acidic conditions [47]. We previously suggest the formation of the phosphomolybdate as an intermediate compound based on a unique absorption spectra of the reduced product that shows close similarity to Mo-blue produced in the phosphate determination method using ascorbic acid as the reducing agent $[25,48,49]$.

The telltale Mo-blue spectra with a peak increase at $865 \mathrm{~nm}$ and a shoulder at $710 \mathrm{~nm}$ is a signature spectrum for reduced phosphomolybdate species $[48,49]$ and is seen in a majority of the Mo-reducing bacteria to date [31-40]. The unique spectrum indicating a common species is involved. Further identification of this species would reveal its structure and once the purified enzyme structure is solved, software 
such as AutoDock can be used to model the site of the reduction. It is interesting to note that in enzymatic chromate reduction, an intermediate species dichromate with a high negative oxidation state has been observed to dock at the lysine residues and heme centres at the chromate reductase enzyme active site responsible for dichromate stabilization and proton and electron transfer activities. This leads to reduction to the insoluble oxidation state [50]. Due to a similar high negative charge of the phosphomolybdate albeit with a very large structure, the mechanism of reduction could be similar.

The ion exchange stage, though vital as a purification step, removes much of enzyme activity. This was also observed during the purification of the enzyme from EC 48 [33]. Probably, a soluble coenzyme was removed during adsorption to the exchanger or this enzyme is extremely heat-labile in strain DRY1. To date, the enzyme responsible for the Mo-reducing activity in EC 48 or any other bacterium has never been purified. Ariff et al. manage to partially purify Mo-reducing enzyme from the bacterium Enterobacter cloacae strain 48 or EC 48 up to the stage of ammonium sulphate fractionation [51]. Further purification using gel filtration on Sephadex G 200 was not successful since no active peak containing Mo-reducing enzyme activity was detected. The apparent $K_{m}$ for phosphomolybdate, NADH, and NADPH were higher compared to $0.32,1.65$, and $2.13 \mathrm{mM}$, respectively, for EC 48 [33] suggesting lower affinity of the electron acceptor and donors to the Mo-reducing enzyme from this bacterium compared to EC 48. NADH is the more preferred substrate to NADPH due to the lower apparent $K_{m}$ values obtained in EC 48 [33] and in this work.

The only known enzyme which could reduce molybdate is molybdate reductase [29]. The enzyme catalyses the reduction of $\mathrm{Mo}(6+)$ to the $(4+)$ oxidation state before its integration with the sulphur atoms of a pterin derivative named molybdopterin, cofactor of molybdoenzymes. The purification of the Mo-reducing enzyme would ultimately solve a century-old phenomenon.

The inhibition by toxic metal ions in this study is seen in all of the Mo-reducing bacteria [25, 30-40] and in other heavy-metal reducing bacteria as well [52-54]. The inhibition of metal-reducing activity by heavy metals generally indicates an enzymatic origin and not abiotic [42-44].

In contrast to previous results in EC 48 [16], our results suggest that the electron transport chain (ETC) of this bacterium is not the site of molybdate reduction. In EC 48 the role of the electron transport chain is concluded based on the inhibition of molybdate reduction by cyanide [16]. We recently demonstrated that cyanide causes the reaction mixture to become very alkaline and this was the reason for the inhibition. When the reaction mixture was neutralized upon the addition of cyanide, no inhibition of molybdate reduction to Mo-blue was seen [31]. Similar negative results for cyanide and other respiratory inhibitors have been obtained with recently isolated Mo-reducing bacteria [31-40] confirming that the electron transport chain is not involved in molybdate reduction. The respiratory inhibitors used in this work inhibit certain sites of the ETC. Rotenone is an inhibitor to NADH dehydrogenase whilst sodium azide and cyanide are inhibitors to the terminal cytochrome d oxidase. Antimycin A is an inhibitor to cytochrome b. [55]. The use of respiratory to probe the location or identity of other metal-reducing enzymes in various studies has shown mixed results. Respiratory inhibitors tested in this work such as azide, rotenone, and cyanide had failed to inhibit chromate reduction in E. coli [54] and in Pseudomonas mendocina [56], while cyanide and azide inhibit the reduction of chromate in Bacillus subtilis [53] and oxidation of arsenite in Alcaligense sp. [52].

\section{Conclusion}

In conclusion, we have isolated and characterized a molybdenum-reducing bacterium from Antarctic soil. The low optimal temperature requirement for molybdenum reduction confirms the psychrotolerant property of this organism. To our knowledge, this is the first report of an Antarctic bacterium able to reduce molybdate to molybdenum blue. We have studied the effect of nitrogen source and electron donors, temperature, phosphate, and molybdate on the reduction of molybdate to molybdenum blue in this bacterium. Only a partial purification of the enzyme was achieved due to the fact that the low enzyme yield of the final step prevents further addition of a chromatographic step. The similarities and differences seen in this work reflect the unique characteristics of Moreducing enzyme from different bacteria. The inability of the respiratory inhibitors to abolish Mo-reducing enzyme activity indicates that the electron transport chain is not the site of reduction. The information obtained in this work is not only important for contributing to the understanding of fundamental mechanism of molybdate reduction but will be extremely important in future works on the bioremediation of molybdenum in polar environments.

\section{Abbreviations}

LPM: Low phosphate medium

HPM: High phosphate medium.

\section{Conflict of Interests}

The authors declare that there is no conflict of interests regarding the publication of this paper.

\section{Acknowledgments}

This work was supported by the research grants from the Minister of Science, Technology and Innovation (MOSTI) and the Academy Sciences of Malaysia (ASM). The authors would like to thank the Argentinean Institute of Antarctica (IAA) for providing logistics support during the expedition to Antarctica. 


\section{References}

[1] D. H. Nies, "Heavy metal-resistant bacteria as extremophiles: molecular physiology and biotechnological use of Ralstonia sp. CH34," Extremophiles, vol. 4, no. 2, pp. 77-82, 2000.

[2] R. K. Upreti, V. Sinha, R. Mishra, and A. Kannan, "In vitro development of resistance to arsenite and chromium-VI in Lactobacilli strains as perspective attenuation of gastrointestinal disorder," Journal of Environmental Biology, vol. 32, no. 3, pp. 325-332, 2011.

[3] R. A. Wuana and F. E. Okieimen, "Heavy metals in contaminated soils: a review of sources, chemistry, risks and best available strategies for remediation," ISRN Ecology, vol. 2011, Article ID 402647, 20 pages, 2011.

[4] A. Branzini and M. S. Zubillaga, "Comparative use of soil organic and inorganic amendments in heavy metals stabilization," Applied and Environmental Soil Science, vol. 2012, Article ID 721032, 7 pages, 2012.

[5] C. Neunhäuserer, M. Berreck, and H. Insam, "Remediation of soils contaminated with molybdenum using soil amendments and phytoremediation," Water, Air, and Soil Pollution, vol. 128, no. 1-2, pp. 85-96, 2001.

[6] G. G. Claridge, I. B. Campbell, H. K. Powell, Z. H. Amin, and M. R. Balks, "Heavy metal contamination in some soils of the McMurdo Sound region, Antarctica," Antarctic Science, vol. 7, no. 1, pp. 9-14, 1995.

[7] A. B. Crockett and G. J. White, "Mapping sediment contamination and toxicity in Winter Quarters Bay, Mcmurdo Station, Antarctica," Environmental Monitoring and Assessment, vol. 85, no. 3, pp. 257-275, 2003.

[8] I. R. Santos, E. V. Silva-Filho, C. E. G. R. Schaefer, M. R. Albuquerque-Filho, and L. S. Campos, "Heavy metal contamination in coastal sediments and soils near the Brazilian Antarctic Station, King George Island," Marine Pollution Bulletin, vol. 50, no. 2, pp. 185-194, 2005.

[9] R. N. Horton, W. A. Apel, V. S. Thompson, and P. P. Sheridan, "Low temperature reduction of hexavalent chromium by a microbial enrichment consortium and a novel strain of Arthrobacter aurescens," BMC microbiology, vol. 6, no. 5, 2006.

[10] A. J. Poulain, S. M. Ní Chadhain, P. A. Ariya et al., "Potential for mercury reduction by microbes in the high Arctic," Applied and Environmental Microbiology, vol. 73, no. 7, pp. 2230-2238, 2007.

[11] G. K. Davis, "Molybdenum," in Metals and Their Compounds in the Environment, Occurrence, Analysis and Biological Relevance, E. Merian, Ed., pp. 1089-1100, VCH Weinheim, New York, NY, USA, 1991.

[12] D. D. Runnells, D. S. Kaback, and E. M. Thurman, "Geochemistry and Sampling of Molybdenum in Sediments, Soils Plants in Colorado," in Molybdenum in the Environment, W. R. Chappel and K. K. Peterson, Eds., Marcel and Dekker, New York, NY, USA, 1976.

[13] E. J. Underwood, "Environmental sources of heavy metals and their toxicity to man and animals," Progress in Water Technology, vol. 11, no. 4-5, pp. 33-45, 1979.

[14] P. D. Rowley, P. L. Williams, and D. E. Pride, "Mineral occurrences of antarctica, petroleum and mineral resources of antarctica," in U.S. Geological Survey Circular, J. C. Behrendt, Ed., pp. 25-49, 1983.

[15] K. R. Wood, "The uncertain fate of the Madrid Protocol to the Antarctic Treaty in the maritime area," Ocean Development and International Law, vol. 34, no. 2, pp. 139-159, 2003.
[16] B. Ghani, M. Takai, N. Z. Hisham et al., "Isolation and characterization of a $\mathrm{Mo}^{6+}$-reducing bacterium," Applied and Environmental Microbiology, vol. 59, no. 4, pp. 1176-1180, 1993.

[17] H. C. Bimboim and J. Doly, "A rapid alkaline extraction procedure for screening recombinant plasmid DNA," Nucleic Acids Research, vol. 7, no. 6, pp. 1513-1523, 1979.

[18] R. Devereux and S. S. Wilkinson, "Amplification of ribosomal RNA sequences," in Molecular Microbial Ecology Manual, Netherland, A. D. L. Akkermans, J. D. Van Elsas, and F. J. De Bruijn, Eds., pp. 1-17, Kluwer Academic Publishing, 2nd edition, 2004.

[19] J. D. Thompson, D. G. Higgins, and T. J. Gibson, "CLUSTAL $\mathrm{W}$ : improving the sensitivity of progressive multiple sequence alignment through sequence weighting, position-specific gap penalties and weight matrix choice," Nucleic Acids Research, vol. 22, no. 22, pp. 4673-4680, 1994.

[20] J. Felsenstein, "Confidence limits on phylogenies: an approach using the bootstrap," Evolution, vol. 39, pp. 783-791, 1985.

[21] N. Saitou and M. Nei, "The neighbor-joining method: a new method for reconstructing phylogenetic trees," Molecular biology and evolution, vol. 4, no. 4, pp. 406-425, 1987.

[22] T. Margush and F. R. McMorris, "Consensus n-trees," Bulletin of Mathematical Biology, vol. 43, no. 2, pp. 239-244, 1981.

[23] R. D. M. Page, “TreeView: an application to display phylogenetic trees on personal computers," Computer Applications in the Biosciences, vol. 12, no. 4, pp. 357-358, 1996.

[24] M. Y. Shukor, M. F. A. Rahman, N. A. Shamaan, C. H. Lee, M. I. A. Karim, and M. A. Syed, "An improved enzyme assay for molybdenum-reducing activity in bacteria," Applied Biochemistry and Biotechnology, vol. 144, no. 3, pp. 293-300, 2008.

[25] M. Y. Shukor, N. A. Shamaan, M. A. Syed, C. H. Lee, and M. I. A. Karim, "Characterization and quantification of molybdenum blue production in Enterobacter cloacae Strain 48 using 12molybdophosphate as the reference compound," Asia-Pacific Journal of Molecular Biology and Biotechnology, vol. 8, pp. 166$172,2000$.

[26] M. M. Bradford, "A rapid and sensitive method for the quantitation of microgram quantities of protein utilizing the principle of protein dye binding," Analytical Biochemistry, vol. 72, no. 1-2, pp. 248-254, 1976.

[27] V. E. Levine, "The reducing properties of microorganisms with special reference to selenium compounds," Journal of Bacteriology, vol. 10, pp. 217-263, 1925.

[28] A. Capaldi and B. Proskauer, "Beitrage zur Kenntnis der Siurebildung bei Typhusbacillen und Bacterium coli," Zeitschrift für Hygiene und Infectionskrankheiten, vol. 23, no. 3, pp. 452474, 1896.

[29] A. M. Campbell, A. Del Campillo-Campbell, and D. B. Villaret, "Molybdate reduction by Escherichia coli K-12 and its chl mutants," Proceedings of the National Academy of Sciences of the United States of America, vol. 82, no. 1, pp. 227-231, 1985.

[30] T. Sugio, Y. Tsujita, T. Katagiri, K. Inagaki, and T. Tano, "Reduction of $\mathrm{Mo}^{6+}$ with elemental sulfur by Thiobacillus ferrooxidans," Journal of Bacteriology, vol. 170, no. 12, pp. 5956-5959, 1988.

[31] M. Y. Shukor, M. A. Syed, C. H. Lee, M. I. A. Karim, and N. A. Shamaan, "A method to distinguish between chemical and enzymatic reduction of molybdenum in Enterobacter cloacae Strain 48," Malaysian Journal of Biochemistry, vol. 7, pp. 71-72, 2002. 
[32] M. F. A. Rahman, M. Y. Shukor, Z. Suhaili, S. Mustafa, N. A. Shamaan, and M. A. Syed, "Reduction of Mo(VI) by the bacterium Serratia sp. strain DRY5," Journal of Environmental Biology, vol. 30, no. 1, pp. 65-72, 2009.

[33] M. Y. Shukor, C. H. Lee, I. Omar, M. I. A. Karim, and M. A. Syed, "Isolation and characterization of a molybdenumreducing enzyme in Enterobacter cloacae strain 48," Pertanika Journal of Science \& Technology, vol. 11, no. 2, pp. 261-272, 2003.

[34] Y. Shukor, H. Adam, K. Ithnin, I. Yunus, N. A. Shamaan, and A. Syed, "Molybdate reduction to molybdenum blue in microbe proceeds via a phosphomolybdate intermediate," Journal of Biological Sciences, vol. 7, no. 8, pp. 1448-1452, 2007.

[35] M. Y. Shukor, S. H. M. Habib, M. F. A. Rahman et al., "Hexavalent molybdenum reduction to molybdenum blue by $S$. Marcescens strain Dr. Y6," Applied Biochemistry and Biotechnology, vol. 149, no. 1, pp. 33-43, 2008.

[36] M. Y. Shukor, M. F. Rahman, Z. Suhaili, N. A. Shamaan, and M. A. Syed, "Bacterial reduction of hexavalent molybdenum to molybdenum blue," World Journal of Microbiology and Biotechnology, vol. 25, no. 7, pp. 1225-1234, 2009.

[37] M. Y. Shukor, M. F. Rahman, N. A. Shamaan, and M. S. Syed, "Reduction of molybdate to molybdenum blue by Enterobacter sp. strain Dr.Y13," Journal of Basic Microbiology, vol. 49, no. 1, pp. S43-S54, 2009.

[38] S. M. Yunus, H. M. Hamim, O. M. Anas, S. N. Aripin, and S. M. Arif, "Mo (VI) reduction to molybdenum blue by Serratia marcescens strain Dr. Y9," Polish Journal of Microbiology, vol. 58, no. 2, pp. 141-147, 2009.

[39] M. Y. Shukor, M. F. Rahman, Z. Suhaili, N. A. Shamaan, and M. A. Syed, "Hexavalent molybdenum reduction to Mo-blue by Acinetobacter calcoaceticus," Folia Microbiologica, vol. 55, no. 2, pp. 137-143, 2010.

[40] M. Y. Shukor, S. A. Ahmad, M. M. M. Nadzir, M. P. Abdullah, N. A. Shamaan, and M. A. Syed, "Molybdate reduction by Pseudomonas sp. strain DRY2," Journal of Applied Microbiology, vol. 108, no. 6, pp. 2050-2058, 2010.

[41] Y. Nogi, H. Takami, and K. Horikoshi, "Characterization of alkaliphilic Bacillus strains used in industry: proposal of five novel species," International Journal of Systematic and Evolutionary Microbiology, vol. 55, no. 6, Article ID 63649, pp. 2309-2315, 2005.

[42] B. Philipp, H. Erdbrink, M. J.-F. Suter, and B. Schink, "Degradation of and sensitivity to cholate in Pseudomonas sp. strain Choll," Archives of Microbiology, vol. 185, no. 3, pp. 192-201, 2006.

[43] J. C. Comolli and T. J. Donohue, "Pseudomonas aeruginosa RoxR, a response regulator related to Rhodobacter sphaeroides PrrA, activates expression of the cyanide-insensitive terminal oxidase," Molecular Microbiology, vol. 45, no. 3, pp. 755-768, 2002.

[44] S. Sinnakkannu, A. R. Abdullah, N. M. Tahir, and M. R. Abas, "Degradation of metsulfuron methyl in selected malaysian agricultural soils," Fresenius Environmental Bulletin, vol. 13, no. 3, pp. 258-261, 2004.

[45] A. M. Hassan, B. M. Haroun, A. A. Amara, and A. Ehab, "Serour production and characterization of keratinolytic protease from new wool-degrading Bacillus species isolated from Egyptian ecosystem," BioMed Research International, vol. 2013, Article ID 175012, 14 pages, 2013.

[46] J. L. Glenn and F. L. Crane, "Studies on metalloflavoproteins. V. The action of silicomolybdate in the reduction of cytochrome $c$ by aldehyde oxidase," Biochimica Et Biophysica Acta, vol. 22, no. 1, pp. 111-115, 1956.

[47] J. D. Lee, Concise Inorganic Chemistry, Van Reinhold, New York, NY, USA, 1977.

[48] L. P. Kazansky and M. A. Fedotov, "Phosphorus- ${ }^{31}$ and oxygen ${ }^{17}$ N.M.R. evidence of trapped electrons in reduced 18molybdodiphosphate $(\mathrm{V}), \mathrm{P}_{2} \mathrm{Mo}_{18} \mathrm{O}_{6}^{28-}$," Journal of the Chemical Society, Chemical Communications, no. 14, pp. 644-646, 1980.

[49] L. S. Clesceri, A. E. Greenberg, and R. R. Trussel, Eds., Standard Methods For the Examination of Wastewater, American Public Health Association, Port City Press, Baltimore, Md, USA, 17th edition, 1989.

[50] M. Sundararajan, A. J. Campbell, and I. H. Hillier, "How do enzymes reduce metals? The mechanism of the reduction of $\mathrm{Cr}(\mathrm{VI})$ in chromate by cytochrome $\mathrm{c} 7$ proteins proposed from DFT calculations," Faraday discussions, vol. 148, pp. 195-228, 2011.

[51] A. B. Ariff, M. Rosfarizan, B. Ghani, T. Sugio, and M. I. A. Karim, "Mo-reducing enzyme in Enterobacter cloacae strain 48," World Journal of Microbiology and Biotechnology, vol. 13, no. 6, pp. 643-647, 1997.

[52] F. H. Osborne and H. L. Ehrlich, "Oxidation of arsenite by a soil isolate of Alcaligenes," Journal of Applied Bacteriology, vol. 41, no. 2, pp. 295-305, 1976.

[53] C. Garbisu, I. Alkorta, M. J. Llama, and J. L. Serra, "Aerobic chromate reduction by Bacillus subtilis," Biodegradation, vol. 9, no. 2, pp. 133-141, 1998.

[54] H. Shen and Y.-T. Wang, "Characterization of enzymatic reduction of hexavalent chromium by Escherichia coli ATCC 33456," Applied and Environmental Microbiology, vol. 59, no. 11, pp. 3771-3777, 1993.

[55] R. M. C. Dawson, D. C. Elliott, W. H. Elliott, and K. M. Jones, Eds., Data For Biochemical Research, Clarendon Press, Oxford, UK, 1969.

[56] J. M. Rajwade, P. B. Salunke, and K. M. Pknikar, "Biochemical basis of chromate reduction by Pseudomonas mendocina Biohydrometallurgy and the Environment," in Proceedings of the International Biohydrometallurgy Symposium, R. Amils and A. Ballester, Eds., pp. 105-114, Elsevier, New York, NY, USA, 1999. 

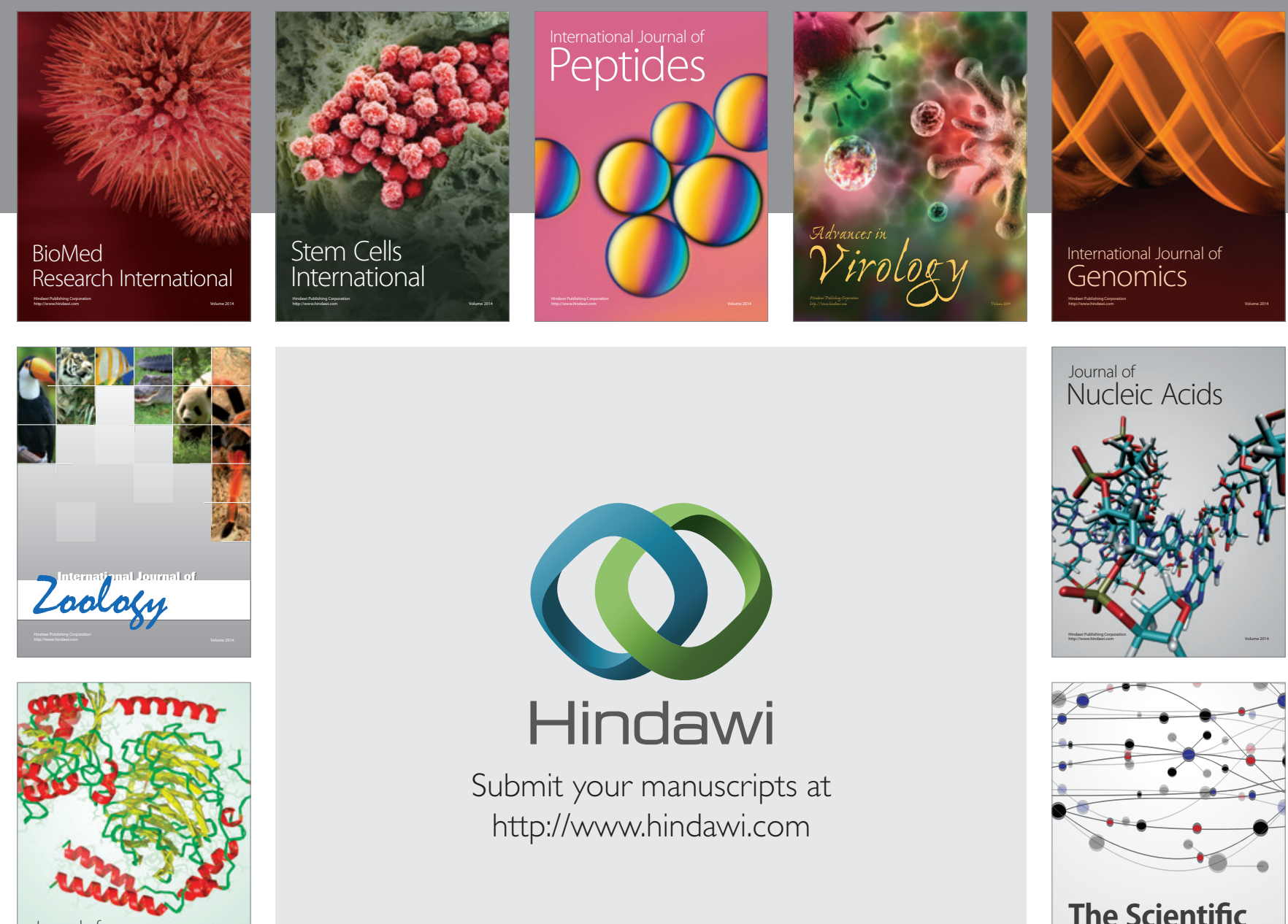

Submit your manuscripts at

http://www.hindawi.com

Journal of
Signal Transduction
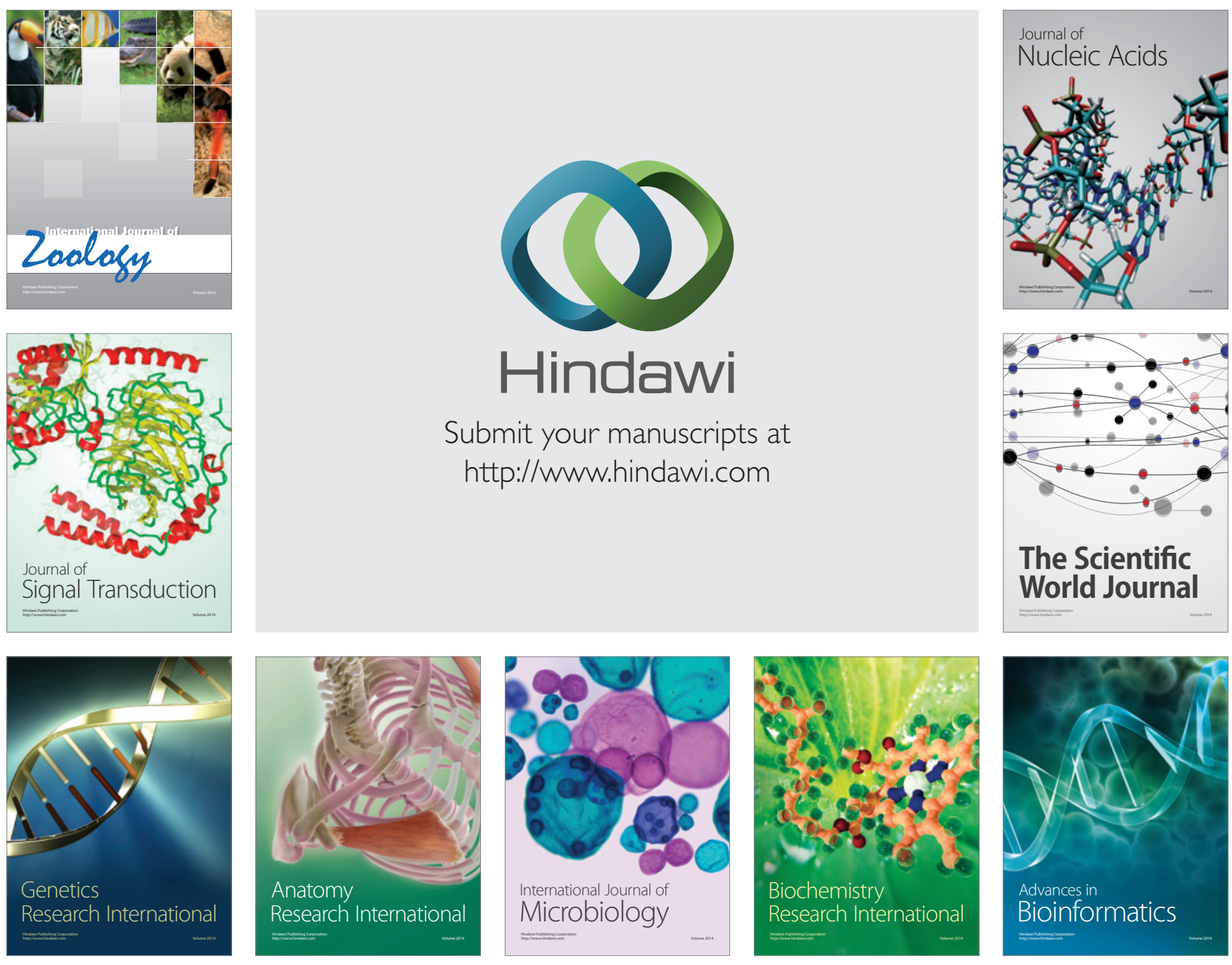

The Scientific World Journal
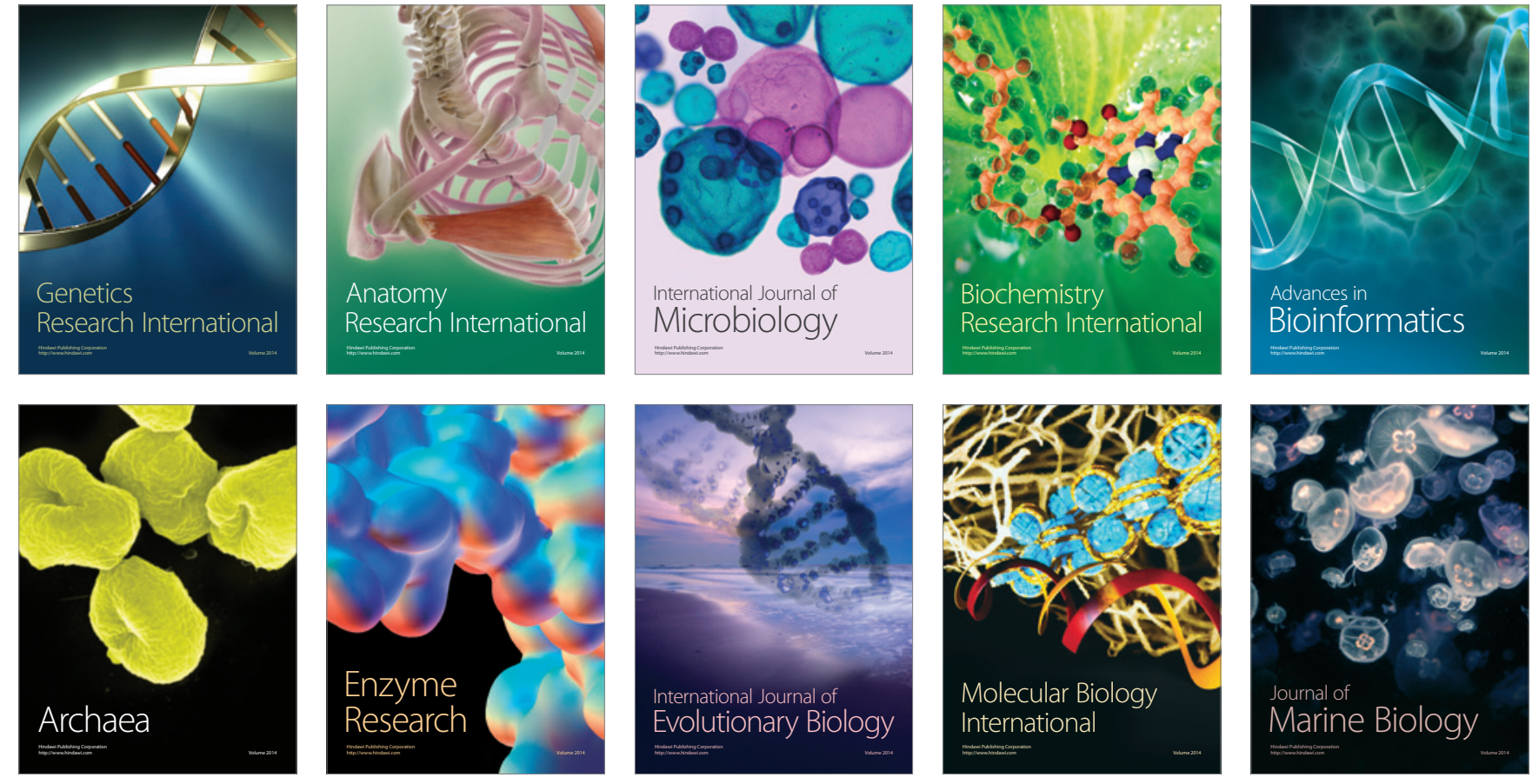